\title{
CONGENITAL ANOMALIES OF THE KIDNEY AND URINARY TRACT IN CHILDREN BORN SMALL FOR GESTATIONAL AGE
}

\author{
Aleksandra Janchevska ${ }^{1}$, Zoran Gucev ${ }^{1}$, L. Tasevska-Rmus ${ }^{1}$, Velibor Tasic ${ }^{1}$ \\ ${ }^{1}$ University Children's Hospital Skopje, Medical Faculty Skopje, Macedonia
}

Corresponding Author: Aleksandra Janchevska, MD, PhD student Department of endocrinology and genetics University Children's Hospital Skopje, Medical Faculty Skopje, Macedonia, Mother Teresa 17, 1000 Skopje, Macedonia Email: dr.sasha1969@yahoo.com

Supporeted by a grant from the International Centre for Genetic Engineering and Biotechnology, ICGEB REF. NO. CRP/MAC13-01

\section{ABSTRACT}

Introduction: Congenital anomalies of the kidney and urinary tract (CAKUT) represent several types of malformations with occurrence of 1 in about 500 live births.

Objective: Small for gestation age (SGA) may influence in prevalence of CAKUT and progression of chronic kidney disease (CKD) in children. The aim of this study was to elaborate our experiences with detected CAKUT in a cohort of SGA born children in Macedonia.

Methods: Our cohort consisted of 100 SGA born children investigated for associated congenital anomalies of urinary tract. We analyzed anthropometric and clinical birth data in children with diagnosed CAKUT and estimated the stage and time of onset of CKD by biochemical and imaging technics.

Results: We revealed 7 (7.0\%) SGA born children with congenital anomalies of the urinary tract. Their mean birth weight was very low $1855 \mathrm{gr}(-3.93 \mathrm{SDS})$ and the birth length $45.57 \mathrm{~cm}(-2.17 \mathrm{SDS})$, as well. A significant growth failure with reduced weight and BMI were noticed at the time of diagnosis. A diagnosis of CAKUT in 4/7 was established in the first few months of life, but in others 3 later in early childhood. Three children revealed with unilateral kidney agenesis, 2 had hypo-dysplastic kidneys and in 2 children was found vesicoureteral reflux. Normal glomerular filtration rate was estimated in 2 children with CAKUT. Stage 2 CKD with GFR $60-90 \mathrm{ml} / \mathrm{minx} 1.73 \mathrm{~m}^{2}$ had 3 children, 1 patient was graded in stage 3 and one child needed kidney transplantation, stage 5 CKD.

Conclusions: We presented 7 SGA born children with CAKUT. An early recognition, assessment and treatment of these anomalies might improve their quality of life.

Key words: born small for gestational age, Congenital anomalies of the kidney and urinary tract (CAKUT), birth weight, birth length, glomerular filtration rate

\section{INTRODUCTION}

An entity/acronym - Congenital anomalies of the kidney and urinary tract (CAKUT) covers wide range of renal and urinary tract anomalies with various degree of severity. These structural anomalies may be presented as complete renal agenesis, as the most severe, to renal hypodysplasia, multicystic kidney dysplasia, duplex renal collecting system, uret- eropelvic junction obstruction (UPJO), megaureter, posterior urethral valves (PUV), and vesicoureteral reflux (VUR).

CAKUT might be detected in 1 of 500 live newborns. The most severe of these anomalies are fatal for 1 of 2,000 infants during the first month of life. Their incidence is higher in boys, although girls might be also affected. Predominantly they are asymptomatic and not associated with another anom- 
aly. There is an evidence of their association with other malformations in syndromic disorders, as in papillorenal syndrome, Meckel-Gruber syndrome, trisomy 18 , asplenia, polysplenia etc. $[1,2]$.

In the majority of patients with CAKUT the inheritance is autosomal dominant with incomplete penetrance, but not all of the family members have the same phenotype expression although they carry the same genetic alteration. Renal anomalies are detected in close relatives of up to $10 \%$ of CAKUT patients. Monogenic forms of CAKUT are caused by mutations in $H N F 1 B$ and $P A X 2$ genes. The Mutations in $H N F 1 B$ and $P A X 2$ genes that cause syndromic disorders are detected in only 5 to $10 \%$ of cases. In 7 affected Sardinian family members with CAKUT by Sanna-Cherchi et al. a heterozygous splice mutation of dual serine/threonine and tyrosine protein kinase gene (DSTYK, MIM 612666.0001) was found [3-7].

Short stature is the most common expected complication in children born SGA. But, they are also at risk for developing obesity, hypertension, insulin resistance, diabetes and cardiovascular diseases in adulthood. These children are with increased risk of renal failure and electrolyte imbalances, as well [8]. Therefore, it is more interesting to investigate the influence of SGA in children with CAKUT if both may contribute to developing the same complications.

SGA is a potential risk factor which may have an influence in increasing the prevalence of the congenital kidney and urinary tract anomalies in children and the progression of CKD, as well. The aim of this study was to elaborate our experiences with detected CAKUT in a relatively small cohort of SGA born children in Macedonia. We followed the established criteria for diagnose of CAKUT in children and their further follow up.

\section{METHODS}

The analyzed data are from a cohort of 100 children born small for gestational age. SGA is defined as birth weight and/or length or at least 2 standard deviations (SD) below the mean for gestational age (GA) [9] born at term, whether they remained short after 4 year old or achieved catch up growth. The main interest in this study are patients with diagnosed congenital disorders of urinary tract.

We investigated several variables taken from their first visit in the study. The clinical birth data was evaluated by birth length (BL), birth weight (BW), BL standard deviation score (SDS) and BW SDS. The investigated anthropometrical data were: chronological age, gender, height (centimeters), weight (kilograms) and body mass index (BMI in $\mathrm{kg} / \mathrm{m}^{2}$ ). The diagnose of CAKUT was established by biochemical and imaging technics.

Glomerular filtration rate (GFR) is the most adequate measurement for estimation of the level of kidney function and the stage of kidney disease. GFR in children is stated normal if it is above $90 \mathrm{ml} /$ $\mathrm{min} / 1.73 \mathrm{~m}^{2}$, although with an evidence of functional, morphological or other kidney abnormality. If GFR is $60-89 \mathrm{ml} / \mathrm{min} / 1.73 \mathrm{~m}^{2}$ it resembles the CKD stage 2. GFR $30-59 \mathrm{ml} / \mathrm{min} / 1.73 \mathrm{~m}^{2}$ is estimated as CKD stage 3 and GFR $15-29 \mathrm{ml} / \mathrm{min} / 1.73 \mathrm{~m}^{2}$ as stage 4 and if GFR is less than $15 \mathrm{ml} / \mathrm{min} / 1.73 \mathrm{~m}^{2}$ that is stage 5 CKD.

CAKUT is very difficult to notice in early childhood until the clinical manifestations do not become apparent. Zhang et al., 2011 [10] recommended ultrasonography as the most preferred screening method for detecting CAKUT in children. There are several other imaging technics that might be useful for detection of these anomalies as radionuclide scanning, voiding cystourethrography (VCUG), X-ray com-

Table 1. Analyzed parameters of SGA born children with CAKUT

\begin{tabular}{|c|c|c|c|c|c|c|c|c|c|c|c|c|c|c|}
\hline & BW & BW & BL & BL & CA & Gender & $\mathbf{H}$ & $\mathbf{H}$ & W & W & GFR & PRD & BMI & BMI \\
\hline No & $\mathrm{g}^{\mathrm{r}}$ & SDS & cm & SDS & $\mathbf{y}$ & - & cm & SDS & kg & SDS & $\begin{array}{c}\mathrm{ml} / \min \mathrm{x} \\
1,73 \mathrm{~m}^{2}\end{array}$ & - & $\mathrm{kg} / \mathrm{m}^{2}$ & SDS \\
\hline 1 & 1300 & $-6,4$ & 47 & -2 & 12 & M & 123,50 & $-3,30$ & 23,00 & $-3,51$ & 97,2 & agenesio renis & 15,08 & $-1,41$ \\
\hline 2 & 1350 & -6 & 40 & $-5,6$ & 0,1 & $\mathrm{~F}$ & 41,00 & $-6,71$ & 1,85 & $-7,85$ & 9 & agenesio & 11,00 & $-3,76$ \\
\hline 3 & 2370 & $-2,7$ & 47 & $-1,6$ & 5,2 & $\mathrm{~F}$ & 113,00 & 0,94 & 25,00 & 1,98 & 101,2 & agenesio & 19,60 & 2,18 \\
\hline 4 & 1590 & $-3,7$ & 45 & $-1,7$ & 4,3 & M & 92,00 & $-3,10$ & 12,00 & $-3,38$ & 88 & hypodysplasio & 14,81 & $-0,66$ \\
\hline 5 & 2300 & $-2,5$ & 47 & $-1,3$ & 0,3 & $\mathrm{~F}$ & 59,00 & $-0,48$ & 4,60 & $-2,75$ & 61 & multicistic dysplastic & 13,21 & $-3,15$ \\
\hline 6 & 2130 & $-3,2$ & 46 & $-2,1$ & 0,2 & M & 56,00 & $-0,90$ & 4,56 & $-1,57$ & 81,1 & VURgr2 & 14,54 & $-0,90$ \\
\hline 7 & 1950 & -3 & 47 & $-0,9$ & 0 & $\mathrm{~F}$ & 47,00 & $-3,00$ & 2,00 & $-4,00$ & 47,2 & VUR3 & 9,05 & $-4,33$ \\
\hline Average & $1.855,71$ & $-3,93$ & 45,57 & $-2,17$ & 3,18 & & 75,93 & $-2,36$ & 10,43 & $-3,01$ & 69,24 & - & 13,90 & $-1,72$ \\
\hline
\end{tabular}

BW-birth weight, BL-birth length, CA-chronological age, H-height, W-weight, GFR-glomerular filtration rate, 
puted tomography, CT scan and magnetic resonance urography.

\section{RESULTS}

An analysis performed in a cohort of 100 patients born small for gestational age revealed 7 (7.0\%) children with inborn anomalies of urinary tract. Of these 7 children, 4 were girls and 3 were boys.

An estimated clinical birth data showed that the mean birth weight of all children born with primary renal anomalies was low, 1,855 gr or (-3.93 SDS), whilst their birth length was reduced as well, 45.57 $\mathrm{cm}$ or (-2.17 SDS), but less than weight (Table 1).

The anthropometrical parameters of these $7 \mathrm{SGA}$ born children during their first visit and diagnosis establishment showed an evidence of growth failure. The average height was reduced in the whole cohort (-2.36 SDS). The short stature was most evident in children born with weight less than 2,000 grams and in children with very low birth weight (VLBW), less than 1,500 grams. The mean weight in all 7 children was even more reduced than height, $-3.01 \mathrm{SDS}$ at the time of diagnosis. Their BMI of $13.9 \mathrm{~kg} / \mathrm{m}^{2}(-1.72$ SDS) was very low, also.

The diagnosis of CKD in more than half of them, 4/7 children, was established in the first few months of life, and in the other 3 later in the early childhood.

Two children with primary renal disease were diagnosed with normal GFR. Stage 2 CKD had 3 children, one patient was graded in stage 3 , one child needed kidney transplantation with GFR $9 \mathrm{ml} /$ $\min / 1.73 \mathrm{~m}^{2}$, resembling stage $5 \mathrm{CKD}$.

The performed imaging diagnostic technics revealed three patients with agenesis of one kidney, 2 children had dysplastic kidneys and 2 children were found to have vesicoureteral reflux.

\section{DISCUSSION}

Nephrogenesis finishes around the 36 week of gestation. But, if a child is born very premature or with intrauterine growth retardation (IUGR) it is more likely to develop a renal disease due to the reduced nephron number. It was explained, according to Brenner's hyper filtration theory that the reduced nephron number leads to decreased glomerular filtration surface area and, consecutively, to glomerular and systemic hypertension. Hypertension has major influence on the glomerular damage and its sclerosis and on the ending with decreased renal function [11]. Microalbuminuria is the first warning sign for forthcoming impairment of GFR and serious renal disease. Keijser-Veen MG et al., in 2005 presented a study in young adults older than 20 years, born IUGR/SGA, with mainly normal renal function. They found in these patients more often episodes of hypertension and/or microalbuminuria and lower GFR than in patients born with an appropriate gestation age (AGA). These authors suggested that SGA leads to renal failure in adulthood [12].

There are several studies which implicate the influence of the urinary tract anomalies on the birth weight and length and the growth spurt during childhood. Karlberg et al. found that all detected patients with CKD were born with reduced BW and BL SDS by 1 SDS [13]. Franke et al. in their study showed significantly elevated rate of SGA and prematurity in children with congenital CKD [14]. Zivicnjak et al. followed up the growth pattern in boys with CKD. Their growth failure was most evident in the early childhood especially during the first year of life. They did not achieve catch up growth, but it speeded up before puberty, slightly slowed down during puberty, and finally, the late speed up was found only until early adulthood [15].

In our cohort of 100 SGA born children we found 7 patients with congenital anomalies of the urinary tract. The estimated BW of these 7 children was low (-3.93 SDS) or 1,855gr with less reduced BL $(-2.17$ SDS $)$, which correlates with data from other studies. It is of note that the growth was seriously affected in our children with CAKUT especially in those with very low BW, less than 1,500 gr. It implicates further investigations and treatment. Growth hormone $(\mathrm{GH})$ treatment is useful in short children with CKD. It improves their growth velocity and the final height [16]. We started with GH treatment in 2 short boys older than 4 years and we will follow their growth achievements.

Approximately $30 \%$ of all prenatally detected congenital anomalies are diagnosed as CAKUT [17]. The most often noticed anomalies are renal hypoplasia, dysplasia, obstructive uropathy and other kidney congenital impairments in patients with chronic kidney disease [18]. It is still unclear why these children are born IUGR or SGA. Mutations, in particular developmental genes were thought to play a major role in the growth reduction and the structural anomalies of the kidneys, other organs and skeleton, as well $[19,20]$. Genetic alterations have been suspects for SGA born children, also. It is of interest to investigate in future, if the same factors responsible for the growth of organs and skeleton influenced the fetal kidney development [21].

The diagnose of CAKUT was established in the majority of our patients (4 out of 7) very early 
in childhood, in the first 6 months of life. In other 2 children at the age of 5 and 12 years, respectively. The absence of one kidney is the most common detected congenital malformation in our cohort of SGA born patients. It was noticed in three children. Unilateral renal hypo-dysplasia with or without cystic formations was found in 2 patients as vesicoureteral reflux as well. VUR in one patient was staged as grade 2 , but in other as stage 3 . An estimated normal GFR was detected in 2 children with unilateral kidney agenesis. Stage 2 of CKD had 2 children with hypo-dysplastic kidneys and a boy with VUR. CKD staged third grade had a girl with VUR. Data from other studies revealed more than one third of patients with CAKUT need surgical treatment. Only one patient of our study $1 / 7$ underwent kidney transplantation due to renal failure.

Our further goal is to investigate if any of our patients with CAKUT have known genetic alteration regarding that or being born small for gestational age.

\section{CONCLUSION}

Children born small for gestational age have an increased risk of morbidity and mortality in adulthood due to the development of several different diseases. Their earlier recognition and treatment lead to better life quality and longevity.

\section{REFERENCES:}

1. Renkema KY, Winyard PJ, Skovorodkin IN et al. Novel perspectives for investigating congenital anomalies of the kidney and urinary tract (CAKUT). Nephrol Dial Transplant. 2011. 26; 3843-3851.

2. Palacios Loro ML, Segura Ramírez DK, Ordoñez Álvarez FA, Santos Rodríguez F. Congenital anomalies of the kidney and urinary tract. A vision for the paediatrician. An Pediatr (Barc). 2015; 83(6):442.

3. Weber S. Novel genetic aspects of congenital anomalies of kidney and urinary tract. Curr Opin Pediatr. 2012; 24(2):212-8.

4. Sanna-Cherchi S, Caridi G, Weng PL et al. Localization of a gene for nonsyndromic renal hypodysplasia to chromosome 1p32-33. Am J Hum Genet. 2007; 80: 539-549.

5. Sanna-Cherchi S, Sampogna RV, Papeta N et al. Mutations in DSTYK and dominant urinary tract malformations. New Eng J Med. 2013; 369: 621-629.
6. Vivante A, Kohl S, Hwang DY et al. Single-gene causes of congenital anomalies of the kidney and urinary tract (CAKUT) in humans. Pediatr Nephrol. 2014; 29(4):695-704.

7. Song R, Yosypiv IV. Genetics of congenital anomalies of the kidney and urinary tract. Pediatr Nephrol. 2011; 26(3):353-364.

8. Tulassay T, Vásárhelyi B. Birth weight and renal function. Curr Opin Nephrol Hypertens. 2002; 11(3):347-352.

9. Lee PA, Chernausek SD, Hokken-Koelega AC, Czernichow P; International Small for Gestational Age Advisory Board. International Small for Gestational Age Advisory Board consensus development conference statement: management of short children born small for gestational age, April 24-October 1, 2001. Pediatrics. 2003; 111(6 Pt 1):1253-1261.

10. Zhang B, Wang H, Sun $\mathrm{N}$ et al. Incidence, diagnosis and treatment of children's congenital abnormalities of the kidney and urinary tract detected in ultrasound screening. Zhonghua Er Ke Za Zhi. 2011; 49(7):534-538.

11. Brenner BM, Anderson S. The interrelationships among filtration surface area, blood pressure, and chronic renal disease. J Cardiovasc Pharmacol. 1992; 19 (6): S1-S7.

12. Keijzer-Veen MG, Schrevel M, Finken MJ et al. Dutch POPS-19 Collaborative Study Group. Microalbuminuria and lower glomerular filtration rate at young adult age in subjects born very premature and after intrauterine growth retardation. J Am Soc Nephrol. 2005; 16(9):2762-2768.

13. Karlberg J, Schaefer F, Hennicke M et al. Early age-dependent growth impairment in chronic renal failure. European Study Group for Nutritional Treatment of Chronic Renal Failure in Childhood. Pediatr Nephrol. 1996; 10(3):283-287.

14. Franke D, Völker S, Haase S et al. Prematurity, small for gestational age and perinatal parameters in children with congenital, hereditary and acquired chronic kidney disease. Nephrol Dial Transplant. 2010; 25(12):3918-24.

15. Zivicnjak M, Franke D, Filler G et al. Growth impairment shows an age-dependent pattern in boys with chronic kidney disease. Pediatr Nephrol. 2007; 22(3):420-429.

16. Mehls O, Lindberg A, Nissel R et al. Predicting the response to growth hormone treatment in short children with chronic kidney disease. J Clin Endocrinol Metab. 2010; 95(2):686-692. 
17. Toka HR, Toka O, Hariri A, Nguyen HT. Congenital anomalies of kidney and urinary tract. Semin Nephrol. 2010; 30(4):374-386.

18. Sanna-Cherchi S, Ravani P, Corbani V et al. Renal outcome in patients with congenital anomalies of the kidney and urinary tract. Kidney Int. 2009; 76(5):528-533.

19. Weber S, Moriniere V, Knuppel T et al. Prevalence of mutations in renal developmental genes in children with renal hypodysplasia: results of the ESCAPE study. J Am Soc Nephrol. 2006; 17:2864-2870.

20. Thomas R, Sanna-Cherchi S, Warady BA et al. HNF1B and PAX2 mutations are a common cause of renal hypodysplasia in the CKiD cohort. Pediatr Nephrol. 2011; 26: 897-903.

21. Argente J, Mehls O, Barrios V. Growth and body composition in very young SGA children. Pediatr Nephrol. 2010; 25(4):679-685.

\title{
Резиме
}

\section{ВРОДЕНИ АНОМАЛИИ НА БУБРЕЗИТЕ И НА УРИНАРНИОТ ТРАКТ КАЈ ДЕЦАТА РОДЕНИ МАЛИ ЗА ВОЗРАСТА}

\author{
Александра Јанчевска ${ }^{1}$, Зоран Гучев ${ }^{1}$, Л. Тасевска-Рмуш ${ }^{1}$, \\ Велибор Тасиќ ${ }^{1}$ \\ ${ }^{1}$ Универзитетска Клиника за детски болести, Медицински Факултет Скопје, Македонија
}

\section{Апстракт}

Вовед: Вродените аномалии на бубрезите и уринарниот тракт (CAKUT) претставуваат неколку видови аномалии што се јавуваат кај 1 од околу 500 живородени.

Цел на трудот и хипотеза: Раѓањето мал за возраста може да влијае на преваленцата на CAKUT-от и прогресијата на хроничната бубрежна болест кај децата. Целта на оваа студија е да ги елаборира нашите искуства во откривањето на CAKUT-от кај децата родени мали за возраста.

Методи: Нашата кохорта се состои од 100 SGA родени деца, кои беа испитувани за асоцирани вродени аномалии на урогениталниот тракт. Ние ги анализиравме антропометриските и клиничките податоци на SGA-родените деца кај кои е поставена дијагнозата CAKUT од породилните картони и го проценивме стадиумот и времето на настанок на хроничната бубрежна болест (ХББ) со помош на биохемиски анализи и имиџинг-техники.

Резултати: Откривме 7 (7\%) SGA-родени деца со вродени аномалии на уринарниот тракт. Нивната средна породилна тежина беше многу ниска - 1855 гр (-3,93 СДС), како и породилната должина $-45,5$ цм $(-2,17 \mathrm{CДC})$. Во моментот на поставувањето на дијагнозата забележавме значаен неуспех во растот, на дофат со намалена телесна тежина и индексот на телесната маса. Дијагнозата CAKUT кај 4/7 од децата беше поставена во првите неколку месеци на животот, а кај другите три подоцна во текот на раното детство. Кај три деца беше најдена агенезија на едниот бубрег, две имаа хиподиспластични бубрези, а кај две деца беше откриен везикоуретрален рефлукс. Кај два деца со CAKUT беше проценета нормална гломеруларна филтрација. Стадиум 2 ХББ со ГФР $60-90 \mathrm{ml} / \mathrm{min} / 1,73 \mathrm{~m}^{2}$ имаа три деца, еден пациент беше класифициран во трет стадиум и на едно дете му беше потребна трансплантација на бубрег, стадиум 5 ХББ.

Заклучоци: Прикажани се 7 SGA-родени деца со CAKUT. Раното препознавање, проценката и лечењето на овие аномалии може да го подобри нивниот квалитет на живот.

Клучни зборови: родени мали за возраста, вродени мани на бубрезите и на уринарниот тракт, породилна тежина, породилна должина, стапка на гломеруларна филтрација 